\title{
Comparatively Investigation of the Quality of Preschool Education Environments in Turkey and the US
}

\author{
Maide Orçan Kaçan \\ Mugla Sitki Kocman University, Turkey \\ Seda Ata \\ Mugla Sitki Kocman University, Turkey \\ Seda Karayol \\ Mugla Sitki Kocman University, Turkey
}

\begin{abstract}
A quality preschool education plays a key role in achieving its objectives. To benefit from this effect of preschool education in a positive way, countries should investigate education systems and the educational methods and practices of other countries so as to understand the problems of education and the factors affecting it. This brings about the need to examine the indicators in regard to processes and structural elements in preschool education institutions. This paper focuses on examining the quality of preschool education classes in Turkey and in the United States comparatively. Descriptive research method was used in the research. Data were collected with ECERS-R in each three classes selected with convenience sampling from three kindergartens in Turkey and three kindergartens in the US. Total score achieved in this instrument and individual scores for seven subscales were examined. In line with the data obtained in this study, the total score of the three classes in kindergartens in the US was found to be higher than those in Turkey. As for the subscales, the classes of the kindergartens in Turkey were found to have higher scores of Language-Reasoning and Program Structure which are two subscales of the instrument. The findings were discussed in the light of the related literature.
\end{abstract}

Keywords: ECERS-R, Turkey, United States (US)

\section{Introduction}

Education systems aim to train qualified individuals that countries need. The quality of education is recognized as the achievement of educational objectives and functions or the way and degree of such achievement (Uysal, 1998; Karsl1, 1998). Quality refers to performing an evaluation for the achievement degree of educational objectives and to an assessment on how studies ensure achievement, the activity in accordance with certain norms, criteria and goals, and whether the graduates possess the desired characteristics. Thus, quality in education means the degree of achievement of the objectives, and the assessment and determination of achievement. It is also an assessment on whether activities and outputs are desirable according to some criteria or objectives (Bakioğlu \& Baltac1, 2010).

It is necessary to properly set quality standards and maintain the process in accordance with standards in preschool education, which is the first and most important step of education. The crucial point in preschool education given to children is the fulfillment of the principles in regard 
to quality. The right outcome can be delivered through extensive identification of these principles and performance of applications under these principles (Ball, 1994).

A systematic, well-equipped, planned, and programmed aid should be provided for children to gain appropriate behaviors, value judgments, and develop basic habits in preschool years of which the child is a major beneficiary. Hence, preschool education institutions need to be prepared in the most ideal way to meet this kind of need in a more conscious and appropriate manner (Oğuzkan \& Oral, 1997). Preschool is a period that forms the basis of other periods in the human life. Accordingly, it is of utmost importance to go through the preschool period in the best way possible and with appropriate experiences as in every period of human life (Oktay, 1999). A qualified preschool education is possible with a well-planned and prepared education program and a well-organized educational environment (Özdemir Beceren, 2012; Koçyiğit, 2012). To that end, a systematic, wide-term, planned, and programmed aid should be provided for children and preschool education institutions should be prepared in the most ideal way to respond to the need in a more conscious and appropriate manner (Güleş, 2013). The perspective of the Ministry of National Education on the concept of quality in education is to ensure that children are raised with rich learning experiences, support their development in all fields, and ensure that they achieve the highest level of development (MEB, 2013). All studies state that the investment made in children at an early age has positive effects on them.

In order to offer high-quality educational support, teachers should be able to support children's use of language, direct it towards their thinking processes, and provide appropriate feedbacks. Moreover, teachers need to interact with children in an appropriate manner and give them a wide range of feedback instead of providing them with the right answer directly (Curby et al., 2009). A quality feedback in preschool education classes means that the feedback should expand learning processes and understanding and encourage children to participate (Pianta, 2003).

Qualification or quality indicators in preschool education are defined differently by different stakeholders (e.g., parents, auditors, administrators) who want to measure quality (Işıkoğlu, 2007). In Turkey, the Ministry of National Education has emphasized in the preschool curriculum that quality needs to be taken into account in parental participation, characteristics of preschool institutions, educational environments, curriculum, staff, and assessment of education (MEB, 2006). The National Association for the Education of Young Children, which is one of the institutions providing accreditation of quality to preschool education institutions, set indicators that determine the quality of the institution based on its suitability for development. Therefore, the association categorizes the institutional quality in 10 domains in this accreditation process: adultchild communication, curriculum, adult-parent communication, teacher competences, staff, physical environment, health and safety, nutrition and food services, and assessment (NAEYC, 2009).

In general terms, given the literature concerning the quality indicators and their definition, quality indicators are discussed in structural and functional domains (Howes et al., 2008; PeisnerFeinberg \& Yazejian, 2010). In the structural quality domain, elements such as teacher competences, teacher-child ratio, and indoor per child are addressed. Teacher-child relationship, education environments rich in stimulants and activities are discussed in the functional quality domain (Howes et al., 2008). In addition, while some researchers (Hujala, Fonsen \& Elo, 2012) argue that structural, mediator, process and effect factors indicate quality in preschool education, most of the researchers agree on the dual construct of quality as structure and process. Over the past two decades, quality scales that contribute to educational and policy decisions have started to be used for sound preschool curricula in several countries (Li et al., 2014). Measuring the global 
quality of early childhood programs, ECERS-R (Keys et al., 2013) consists of 7 subscales: Space and Furnishings, Personal Care Routines, Language-Reasoning, Activities, Interactions, Program Structure, and Parents and Staff. ECERS-R is an instrument used to measure the quality of preschool education in the United States and in international contexts (Göl-Güven, 2009). To date, different versions of ECERS-R have been applied in more than 30 countries with different socioeconomic backgrounds (Hadeed, 2014; Li et al., 2014). Research findings on the use of ECERS-R have had a major impact on preschool practice, research and policy development (Fenech, 2011).

The education systems affect the integrity and development of the society. Therefore, to benefit from this effect of preschool education in a positive way, countries should investigate education systems and the educational methods and practices of other countries so as to understand the problems of education and the factors affecting it. Furthermore, education systems of different countries should be investigated comparatively to expand people's understanding of culture and to offer international communication and understanding (Korkmaz, 2005). Countries create and develop their own education systems. It is thought that other samples should be examined in this formation and development process. In this context, this research aimed to examine the quality of preschool education classes in Turkey and in the US comparatively.

\section{Research Model}

This research utilized the descriptive survey model (Büyüköztürk et al., 2015) which describes a given case as fully and carefully as possible to examine the education environments in preschool institutions in Turkey and the US.

\section{Study Group}

One of the most widely used sampling types in social sciences is convenience sampling. In convenience sampling, researchers select participants from among easy to reach, eligible and volunteered individuals (Gravetter \& Forzano, 2012). In short, convenience sampling is the selection of the convenient sample for the researcher. To this end, schools in close locations to the researchers were selected. The study group of the research was composed of three schools in Turkey and three schools in the US (six preschool education institutions in total). The schools from which the data were collected in both countries are formal preschool education institutions. These institutions are located in similar moderate socioeconomic circles in both countries. The data were collected in the first term of the academic year in both countries.

\section{Instrument}

The research utilized the Early Childhood Environment Rating Scale - Revised (ECERS$R$ ) as the data collection instrument. The original version of ECERS was developed by Harms and Clifford (1980). The scale was adapted to Turkish language and its validity and reliability studies were conducted by Kler Klodya Tovim (1996). The version revised by Harms, Clifford and Creyer (1998) is widely used (Feyman, 2006; Aksoy, 2009). The Early Childhood Environment Rating Scale (ECERS-R) consists of 7 subscales and 43 indicators. These are:

1. Space and Furnishings: Indoor space; Furniture for routine care, play and learning; Furnishings for relaxation and comfort; Room arrangement for play; Space for privacy; Childrelated display; Space for gross motor play; Gross motor equipment

2. Personal Care Routines: Greeting/departing; Meals/snacks; Nap/rest; Toileting/diapering; Health practices; Safety practices

3. Language-Reasoning: Books and pictures; Encouraging children to communicate; Using language to develop reasoning skills; Informal use of language

4. Activities: Fine motor; Art; Music/movement; Blocks; Sand/water; Dramatic play; Nature/science; Math/number; Use of TV, video, and/or computers; Promoting acceptance of diversity 
5. Interaction: Supervision of gross motor activities; General supervision of children (other than gross motor); Discipline; Staff-child interactions; Interactions among children

6. Program Structure: Schedule; Free play; Group time; Provisions for children with disabilities

7. Parents and Staff: Provisions for parents; Provisions for personal needs of staff; Provisions for professional needs of staff; Staff interaction and cooperation; Supervision and evaluation of staff; Opportunities for professional growth

The scoring of the scale is marked on the scoring sheet as "yes", "no" and "not applicable" for each item. The item scores are ranked from 1 (inadequate) to 7 (very good). The researcher can take explanatory notes when necessary. The scoring of the indicators is determined as follows:

1. If any indicator below 1 is marked "Yes", the indicator is rated 1 point.

2. When all indicators below 1 are marked "No" and at least half of the indicators below 3 are marked "Yes", the indicator is rated 2 points.

3. When all indicators below 1 are marked "No" and all indicators below 3 are marked "Yes", the indicator is rated 3 points.

4. When all indicators below 3 are marked "Yes" and at least half of the indicators below 5 are marked "Yes", the indicator is rated 4 points.

5. When all indicators below 5 are marked "Yes", the indicator is rated 5 points.

6. When all indicators below 5 are marked "Yes" and at least half of the indicators below 7 are marked "Yes", the indicator is rated 6 points.

7. When all indicators below 7 are marked "Yes", the indicator is rated 7 points.

8. Where the application of the item is not possible, the score of that item shall be indicated by "NA" (not applicable). Any indicator marked "NA" is ignored in the rating of an item, and items marked "NA" are not used in the calculation of subscale and total scale scores.

The points given in the assessment of the test are defined as follows:

1: inadequate/ 2: inadequate to barely adequate/ 3: barely adequate/ 4: barely adequate to good/ 5: good/ 6: good to very good/ 7: very good

Score of each subscale is the average value achieved by the division of the sum of every item's score by the number of items. Score of the total score is calculated by the division of the sum of subscale scores by the number of items.

\section{Data Collection}

The data of the study were collected by the researcher by means of observation in the institutions included in the study group and face-to-face interviews with the teachers working in the institutions. To perform observations and interviews, the researcher called the selected institutions and got appointments from the administrations. After having informed the administrators of the study and received permission, the teachers were interviewed and informed. Furthermore, the volunteered teachers were observed and interviewed on the days and at the hours decided by them.

\section{Data Analysis}

The research utilized descriptive analysis in the study. In this approach, the data are summarized and interpreted in accordance with predefined themes. The data can be arranged according to the themes achieved by the research results or can be presented by taking into account 
the questions or dimensions used in the interview and observation processes. Associating and making meaning of themes and future predictions in regard to the themes can be among the aspects of interpretations to be made by the researcher (Yıldırım \& Şimşek, 2011). In this study, the data obtained with ECERS-R were interpreted through the support of observations and interviews conducted during the data collection process.

\section{FINDINGS}

This section presents the data obtained with the instrument.

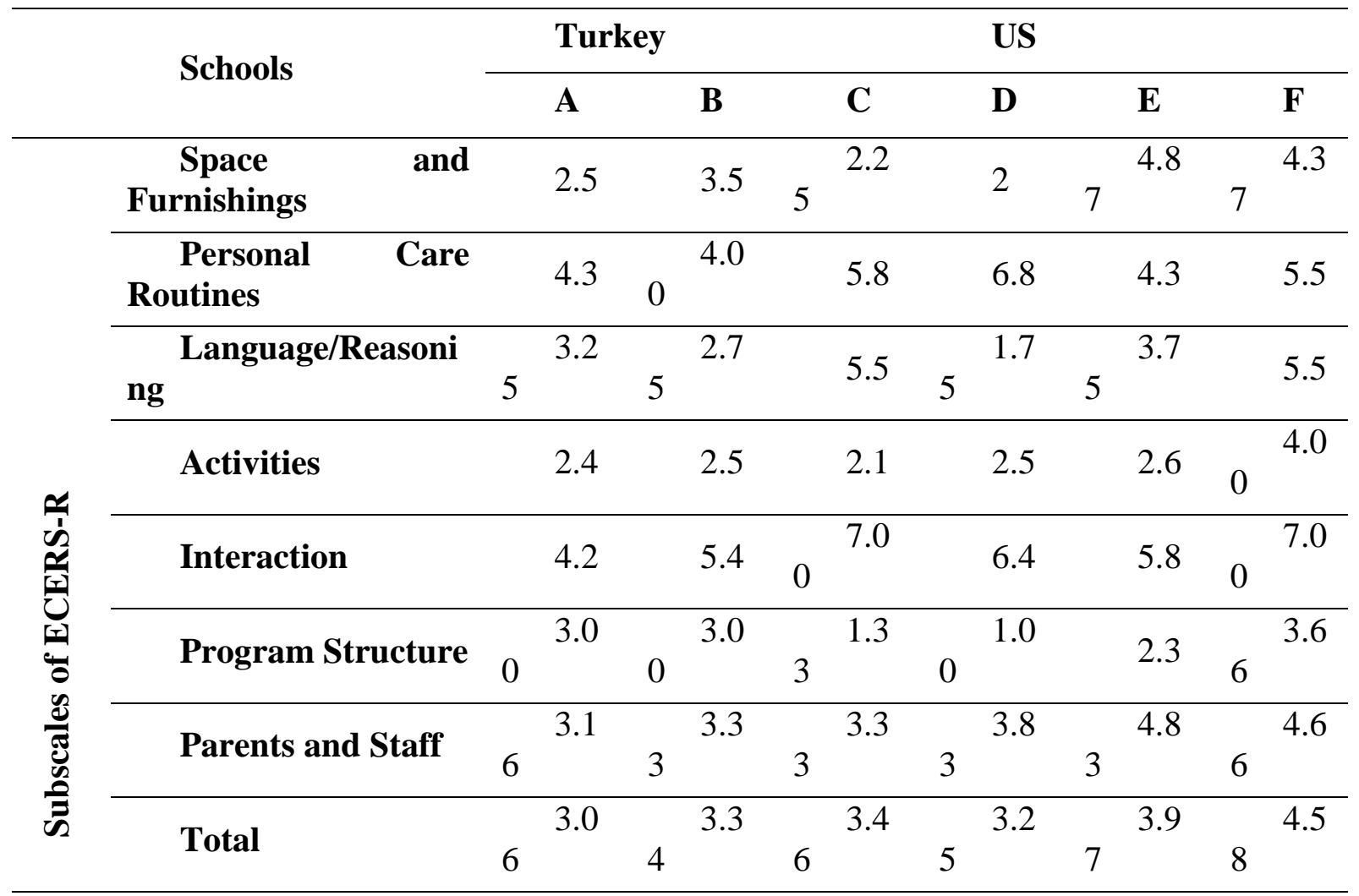

Table 1. Scores of the Subscales of ECERS-R and the Total Scale

The values of the classes selected from the kindergartens in Turkey and the US are given in Table 1. According to Table 1, the class of the school A in Turkey was rated between inadequate and barely inadequate for Space and Furnishings (2.5); between barely inadequate and good for Personal Care Routines (4.3); barely inadequate for Language/Reasoning (3.25); between inadequate and barely inadequate for Activities (2.4); between barely inadequate and good for Interaction (4.2); barely inadequate for Program Structure (3.00); and barely inadequate for Parents and Staff (3.16).

The class of the school B in Turkey was rated barely inadequate for Space and Furnishings (3.5); between barely inadequate and good for Personal Care Routines (4.00); between inadequate and barely inadequate for Language/Reasoning (2.75); between inadequate and barely inadequate for Activities (2.5); good for Interaction (5.4); barely inadequate for Program Structure (3.00); and barely inadequate for Parents and Staff (3.33).

The class of the school $\mathrm{C}$ in Turkey was rated between inadequate and barely inadequate for Space and Furnishings (2.25); good for Personal Care Routines (5.8); good for Language/Reasoning (5.5); between inadequate and barely inadequate for Activities (2.1); very good for Interaction (7.00); inadequate for Program Structure (1.33); and barely inadequate for Parents and Staff (3.33). 
The class of the school D in the US was rated between inadequate and barely inadequate for Space and Furnishings (2.00); between good and very good for Personal Care Routines (6.8); inadequate for Language/Reasoning (1.75); between inadequate and barely inadequate for Activities (2.5); between good and very good for Interaction (6.4); inadequate for Program Structure (1.00); and barely inadequate for Parents and Staff (3.83).

The class of the school $\mathrm{E}$ in the US was rated between inadequate and barely inadequate for Space and Furnishings (4.87); between barely inadequate and good for Personal Care Routines (4.3); barely inadequate for Language/Reasoning (3.75); between inadequate and barely inadequate for Activities (2.6); good for Interaction (5.8); between inadequate and barely inadequate for Program Structure (2.3); and between barely inadequate and good for Parents and Staff (4.83).

The class of the school $\mathrm{F}$ in the US was rated between barely inadequate and good for Space and Furnishings (4.37); good for Personal Care Routines (5.5); good for Language/Reasoning (5.5); between barely inadequate and good for Activities (4.00); very good for Interaction (7.00); barely inadequate for Program Structure (3.66); and between barely inadequate and good for Parents and Staff (4.66).

The mean score of the three classes in Turkey for all of the subscales was calculated to be 24.82. The respective subscale scores of these schools were calculated to be as follows: 2.75 for Space and Furnishings; 4.7 for Personal Care Routines; 3.83 for Language/Reasoning; 2.3 for Activities; 5.53 for Interaction; 2.44 for Program Structure; and 3.27 for Parents and Staff.

The mean score of the three classes in the US for all of the subscales was calculated to be 29.12. The respective subscale scores of these schools were calculated to be as follows: 3.74 for Space and Furnishings; 5.53 for Personal Care Routines; 3.66 for Language/Reasoning; 3.03 for Activities; 6.4 for Interaction; 2.32 for Program Structure; and 4.44 for Parents and Staff.

\section{CONCLUSION, DISCUSSION AND RECOMMENDATIONS}

This research examined the quality of three preschool classes in Turkey and three preschool classes in the United States (six in total) comparatively. The data obtained to this end indicated that total quality rating of the three schools in the US were higher than the total quality rating of the three schools in Turkey. In other words, it can be argued that the preschool education institutions located in the United States are of higher quality than the ones located in Turkey.

Other than two subscales (Language/Reasoning and Program Structure), the preschool education institutions in the US had higher scores of all subscales. With steps to be taken for the quality of preschool education in Turkey once preschool education will become mandatory by 2020 , it is expected that Turkey will compete with other countries both qualitatively and quantitatively. The 2023 Vision of Education announced on 23 October 2018 states that the quality, scope, and accessibility of early childhood education will be increased within three years and that early childhood education will be mandatory for the 5-year-old group. The fact that a written document was published is one of the most important steps taken in recent years on the matter in terms of drawing attention to early childhood and emphasizing its value. Thus, it will pave the way for discussing short- and long-term supportive effects of preschool education in Turkey.

Space and Furnishings: This subscale rates the suitability of physical structure and the material used in the classroom. A well-prepared physical environment and educational program in preschool education institutions enables children to acquire social skills such as taking 
responsibility, interaction with their friends, taking role within group, and cooperation (Demiriz, Ulutaş \& Karadağ, 2011).

The classroom should be inviting and supportive for all children (Bucholz \& Sheffler, 2009). A well-organized classroom environment encourages the development of children's play, their independence, socialization, and helps them to solve the problems they face (Coughlin et al., 1997). It is necessary to provide psychological safety through which students will feel safe and at ease when ensuring the physical safety which is the most basic condition in the physical environment (Weinstein, 1996). In her doctoral thesis, Kurşunlu (2018) explored that the legal physical standards of preschool education institutions in Turkey are not adequately qualified compared to international standards. As for the scores of this subscale, the three schools in the US were found to be in better condition than those in Turkey (the difference between the scores = 0.99). This can be explained by different amounts of budget allocated for preschool classes in the two countries.

Personal Care Routines are activities performed at the same hours at all times such as going to/coming from the school, gathering, cleaning, breakfast, eating, going to toilet, and resting, etc. The adult attitude during the satisfaction of such needs of children serves as foundation based on their perspective of the world, i.e., confidence or lack of confidence in others. A school environment that allows them to know themselves, to tolerate their mistakes with sensitivity, will also affect the self-perception of the child positively (Oktay, 1999). It can be argued accordingly that a better routine is run in the three classes in the US than in the three classes in Turkey (the difference between the scores $=0.83$ ).

Language activities are important in ensuring children's linguistic development as well as providing them with the skills of using the language to express their own feelings and thoughts according to rules and with listening skills (Girgin, 2003). Concerning Language/Reasoning and Program Structure, the mean score of the three schools in Turkey were slightly higher than the mean score of the ones in the US. Therefore, one can say that three classes of the kindergartens in Turkey pay attention to the standards in the Language/Reasoning subscale more or similarly (difference $=0.17$ ).

As for the activities subscale, preschool period covering the first six year of children is the period in which the child's development is the fastest. The education received by the child in this period increases his/her strength of perception and help him/her improve his/her skills and express his/her feelings (Macaroğlu Akgül, 2004). There should be activities which the child can make use of in real life, and the existing activities should be prepared in a way that complies with children's interests and needs and ensures that they achieve meaningful successes and support learning by having fun. For this subscale, the activities in the three kindergarten classes in the United States were found to be higher (difference between the scores $=0.73$ ). This difference can be explained by the regular and supportive implementation of activities in the US classrooms.

Interaction refers to studies that promote the development of relationships between adults and children, among teachers themselves, and between teachers and families (NAEYC, 1996). Communication in the classroom is the multifaceted flow of knowledge, skills, and news between teacher and student, student and student, and parent and environment to achieve targeted gains. The quality of communication allows the child to feel safe, to increase positive behavior, to reduce dropping out of school or absenteeism (Bullard, 2014). For interaction, it can be argued that there is a more positive and supportive climate in the three classes in the US compared to the three classes in Turkey (difference between the scores $=0.93$ ). 
Program Structure affects the disciplinary development and individual development of the child in social life. A program soundly based on the existing foundations of the child increases his/her knowledge capacity and brings new skills to him/her. A suitable program should cover all areas of the child's development (physical, emotional, social, etc.). Thus, the needs of each age group should be met with different programs (NAEYC, 1996). The programs adopted in education should help children to know themselves, develop awareness of their own culture and other cultures, and should support several skills such as social skills, analytical thinking, problem solving, creativity, and aesthetics (Yurtal \& Yaşar, 2008). Therefore, one can say that the three classes of the kindergartens in Turkey pay attention to the standards in the Program Structure subscale more or similarly (difference $=0.12$ ).

Parental participation affects social and emotional development of children positively and plays a key role in children developing positive attitudes and behaviors (Bilgin, 2013). Ensuring the continuity between school and home, strengthening the role of parents in their children's education in the after-school learning process, and making it effective is one of the most important purposes of parental participation (Yaşar-Ekici, 2016). The three kindergarten classes in the US had their highest mean score in the Parents and Staff subscale. Based on this finding, it can be stated that schools in the US give more importance to Parents and Staff. It is accordingly possible to argue that more active participation of parents in preschool education is supported in the three classes of the kindergartens in the US.

As for the total scores, the scores of the three kindergarten classes in the US were higher than the scores of the classes in Turkey (difference between the scores $=4.24$ ). It can be argued that investments for increasing the quality are needed for getting the desired productivity from preschool education in Turkey. However, declared on 23 October 2018, in the 2023 Education Vision, the quality, scope, and access of early childhood will be increased within three years. And also it is stated that early childhood education will be compulsory for 5 years. To be a written document, to draw attention to early childhood, and to emphasize its value in terms of the most recent in this regard is one of the important steps. Turkey is also considered by making all of this work to come to the desired level of the quality of early childhood educational settings.

In the light of the results and limitations of this research, some suggestions were made. The data in this research were collected from a small number of schools with similar socioeconomic backgrounds both in Turkey and the United States. It is recommended that certain concrete steps should be taken to increase quality standards in preschool education following a general survey study to be performed with preschool education institutions with different socioeconomic backgrounds across Turkey. Comparative preschool education studies between different countries can be carried out with the data to be collected from large samples with different socioeconomic backgrounds. In addition, national and international preschool education studies can be conducted to explore the relationship between the quality of current early childhood environments and the preparedness levels for primary school. The 7 subscales addressed in this study can be planned as individual studies to achieve more detailed results. 


\section{References}

Aksoy, P. (2009). Okul öncesi eğitim kurumlarının eğitim ortamlarının niteliğinin bazı değişkenler açısından incelenmesi. Yayınlanmamış yüksek lisans tezi. Ankara Üniversitesi, Eğitim Bilimler Enstitüsü, Ankara.

Bakioğlu, A., \& Baltacı, R. (2010). Akreditasyon, Eğitimde Kalite, Ankara, Nobel Dağıtım

Ball, S. (1994). Education Reform: A Critical and Post-Structural Approach. McGraw Hill Education, New York.

Bilgin, A. H. N. (2004). Çocuk Ruh Sağlı̆̆ı. İstanbul: Morpa.

Bucholz, J. L., \& Sheffler, J. L. (2009). Creating a Warm and Inclusive Classroom Environment: Planning for All Children to Feel Welcome. Electronic Journal for Inclusive Education, 2(4), 1-3. Bullard, J. (2014). Creating environments for learning: Birth to age eight. Boston, Pearson.

Büyüköztürk, Ş., Kılıç Çakmak, E., Akgün, Ö. E., Karadeniz, Ş. ve Demirel, F. (2015). Bilimsel araştırma yöntemleri. Ankara: Pegem Akademi Yayınevi.

Coughlin, P. A., Hansen, K. A., Heller, D., Kaufmann, R. K., Stolberg, J. R., \& Walsh, K. B. (1997). Creating Child-Centered Class-Rooms. Washington, DC: Children Resources International, Inc.

Curby , T. W., Rimm-Kaufman, S. E., \& Ponitz , C. C. (2009). Teacher-child interactions and children's achievement trajectories across kindergarten and first grade. Journal of Educational Psychology , 101, 912-925.

Demiriz, S., Karadağ, A., \& Ulutaş, İ. (2003). Okul öncesi eğitim kurumlarında eğitim ortamı ve donanım. Ankara: Anı.

Fenech, M. (2011). An analysis of the conceptualization of 'quality' in early childhood education and care empirical research: Promoting 'blind spot' as foci for future research. Contemporary Issues in Early Childhood, 12, 102-117.

Feyman, N. (2006). Okul öncesi eğitim kurumlarında kalitenin çocukların gelişim alanları üzerine etkisinin incelenmesi. Yayımlanmamış Yüksek Lisans Tezi, Hacettepe Üniversitesi, Ankara.

Girgin, Ü. (2003). Okumaya Hazırlık Etkinlikleri. Çocukta Dil ve Kavram Gelişimi. Eskişehir: Anadolu Üniversitesi Yayınları.

Gol-Guven, M. (2009). Evaluation of the quality of early childhood classrooms in Turkey, Early Development and Care, 179(4), 437-451.

Gravetter, F. J., \& Forzano, L. B. (2012). Research methods for the behavioral sciences (4th ed.). Belmont, CA: Wadsworth.

Güleş, F. (2013). Okul öncesi eğitimde fiziksel çevreye ilişkin kalite standartlarının belirlenmesi. Yayınlanmamış Doktora Tezi, Selçuk Üniversitesi Sosyal Bilimler Enstitüsü, Konya.

Hadeed, J. (2014). Reliability and validity of the Early Childhood Environment Rating Scale, Revised Edition, ECERS-R in Arabic. Early Child Development and Care, 184 (6), 819-842.

Harms, T., \& Clifford, R. (1980). Early childhood environment rating scale. New York: Teachers College Press.

Harms, T., Clifford, R., \& Cryer, D. (1998). Early childhood environment rating scale-revised. New York: Teachers College Press.

Howes, C., Burchinal, M., Pianta, R., Bryant, D., Early, D., Clifford, R., et al. (2008). Ready to learn? Children's pre-academic achievement in pre-kindergarten programs. Early Childhood Research Quarterly, 23, 27-50.

Hujala, E., Fonsén, E., \& Elo, J. (2012). Evaluating the Quality of the Child Care in Finland. Early Child Development and Care, 182(3-4), 299-314.

Işıkoğlu, N. (2007). Okul öncesi eğitim kurumlarında kalite. Gazi Üniversitesi Mesleki Eğitim Dergisi, 9(18), 37-47.

Karslı, D.K. (1998). Yönetsel Etkililik. Bolu. AİBÜ. Yayınları No 6.

Keys, T. D., Farkas, G., Burchinal, M. R., Duncan, G. J., Vandell, D. L., Li, W., et al. (2013). Preschool center quality and school readiness: Quality effects and variation by demographic and child characteristics. Child Development, 84(4), 1171-1190. 
Koçyiğit, S. (2012). Okul öncesi eğitimin tanımı, amacı, önemi ve ilkeleri. Bulunduğu eser: Zembat, R.(Ed.) Okul Öncesi Eğitime Giriş (pp, 14-26). Ankara: Hedef Yayıncılık.

Korkmaz, T. (2005). Türk ve İngiliz eğitim sistemlerinin karşılaştırılması. Yayımlanmamış Yüksek Lisans Tezi, Uludağ Üniversitesi, Bursa.

Kurşunlu, E. (2018). Türkiye'deki okul öncesi eğitim kurumlarının fiziksel özelliklerinin incelenmesi. Yayımlanmamış Doktora Tezi, Hacettepe Üniversitesi, Ankara.

Li, K., Hu, B., Pan, Y., Qin, J., \& Fan, X. (2014). Chinese Early Childhood Environment Rating Scale (trial) (CECERS): a validity study. Early Childhood Research Quarterly, 29(3), 268-282.

Macaroğlu Akgül, E. (2004). Fen ve Doğa Etkinlikleri Uygulama Kitabı, İstanbul, Morpa Kültür Yayınları.

NAEYC (2009). Developmentally appropriate practice in early childhood programs serving children from birth through age 8. Position statement. Washington, DC: Author.

Oğuzkan, Ş., \& Oral, G. (1997). Okulöncesi Eğitimi. İstanbul: Milli Eğitim Basımevi.

Oktay, A. (1999). Yaşamın Sihirli Yılları: Okul Öncesi Dönem. İstanbul: Epsilon Yayınları

Özdemir Beceren, Y. (2012). Okul öncesi eğitim ortamları. Bulunduğu eser: Zembat, R.(Ed.) Okul Öncesi Eğitime Giriş (s, 180-199). Ankara: Hedef Yayıncılık.

Peisner-Feinberg, E. S., \& Yazejian, N. (2010). Research on program quality: the evidence base. In V. Buysse, \& P. W. Wesley (Eds.), The quest for quality: promising innovations for early childhood programs (pp. 21-45). Baltimore, MD: Paul H. Brookes.

Pianta, R. C. (2003). Standardized observations from pre-K to 3rd grade: A mechanism for improving access to high-quality classroom experiences and practices during the p-3 years(Working paper). New York: Foundation for Child Development.

Uysal, H. (1998). Toplam Kalite Yönetiminin İlköğretime Uygulanabilirliği. G. Ü. Sosyal Bilimler Enstitüsü Yayımlanmamış Yüksek Lisans Tezi, Ankara.

Weinstein, C. S. (1996). Secondary Classroom Management: Lessons From Research and Practice, New York: McGraw Hill.

Yaşar-Ekici, F. (2016). Okul öncesi öğretmen adayları ile diğer alanlardaki öğretmen adaylarının aile katılımına yönelik tutumlarının karşılaştırılması. International Journal of Social Sciences and Education Research, 2(4), 1322-1337.

Yıldırım, A., \& Şimşek, H. (2011). Sosyal Bilimlerde Nitel Araştırma Yöntemleri (8. Baskı). Ankara: Seçkin Yayıncılık.

Yurtal, F., \& Yaşar, M. (2008). Sınıf Yönetimini Etkileyen Faktörler. In Y. A. Arnas \&F. Sadık (Eds.), Okul Öncesi Eğitimde Sınıf Yönetimi içinde (pp. 62-82) Ankara: Kök Yayıncılık. 